\title{
【論文】
}

\section{都市ごみ焼却施設における排ガス処理技術の適用 による塩化水素と二酸化硫黄の排出削減量}

\author{
谷川昇 ${ }^{*}$ ・浦 野 紘 平 ${ }^{* *}$
}

\begin{abstract}
【要 旨】都市ご焼却施設において, 塩化水素 $(\mathrm{HC} \ell)$ と二酸化硫黄 $\left(\mathrm{SO}_{2}\right)$ の処理技術等の適用に よる排出低減効果を明らかにし，東京 23 区と日本全国における都市ごみ焼却施設からの $\mathrm{HC} \ell$ と $\mathrm{SO}_{2}$ の排出削減量を考察した。

処理技術を採用しない場合の $\mathrm{HC}$ 排出濃度は, ごみ中のプラスチック類の分別方法, 排ガス冷却方 法, 集じん装置の種類によって異なり，約 $300 \sim 650 \mathrm{ppm}$ であった。また， $\mathrm{SO}_{2}$ 排出濃度は，集じん 装置の種類によって異なり, 約 $44 \sim 64 \mathrm{ppm}$ であった。

電気集じん装置 $(\mathrm{EP})$ を組み合わせた粉体噴射法を採用した場合には, HC $\ell$ 排出濃度は約 200 $410 \mathrm{ppm}, \mathrm{SO}_{2}$ 排出濃度は約 $30 \mathrm{ppm}$ であった。一方， $\mathrm{EP}$ を組み合わせた湿式法を採用した場合には， $\mathrm{HC}$ 排出濃度は約 $6 \sim 12 \mathrm{ppm}, \mathrm{SO}_{2}$ 排出濃度は約 $2 \mathrm{ppm}$ であった。

東京 23 区の都市ごみ焼却施設においては, 1980 年からの 15 年間に焼却ごみ量が約 1.4 倍に增加した が, $\mathrm{HC} \ell$ と $\mathrm{SO}_{2}$ の排出負荷量は，排ガス処理技術の採用によって微增傾向に抑えられている。また， 1992 年の日本全国における都市ごみ焼却施設からの $\mathrm{HC} \ell$ と $\mathrm{SO}_{2}$ の排出負荷量は，それぞれ $9.1 \times 10^{4}$ $\mathrm{t} / \mathrm{y}$ と $1.8 \times 10^{4} \mathrm{t} / \mathrm{y}$ 程度と推算され，排ガス処理技術による $\mathrm{HC} \ell$ と $\mathrm{SO}_{2}$ の排出削減量は，それぞれ $7.6 \times 10^{4} \mathrm{t} / \mathrm{y}$ と $2.0 \times 10^{4} \mathrm{t} / \mathrm{y}$ 程度と推算された。

キーワード：都市ごみ焼却，塩化水素，二酸化硫黄，排出負荷量，排ガス処理
\end{abstract}

\section{1. 緒言}

都市ごみ焼却施設に採用されている塩化水素 $(\mathrm{HC} \ell)$ と二酸化硫黄 $\left(\mathrm{SO}_{2}\right)$ を同時に処理する技術（以下，処 理技術と記す）は，全乾式法，半乾式法および湿式法に 大別される ${ }^{1-3)}$ 。全乾式法は粉体状の炭酸カルシウムや 水酸化カルシゥムなどのアルカリ剤を，半乾式法はスラ

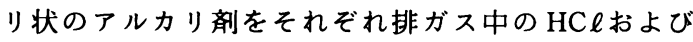
$\mathrm{SO}_{2}$ と反応させ, 生成した塩化物や硫酸塩等を集じん 装置によって除去する方法である。また，湿式法は水酸 化ナトリウムなどでほぼ中性から弱アルカリ性に保った

原稿受付 1996.9.13

* 東京都清掃研究所

** 横浜国立大学工学部物質工学科

連絡先 : $\bar{\top} 135$ 東京都江東区青海二丁目地先
水溶液とダストを除去した排ガスを接触させ，排ガス中 の $\mathrm{HC} \ell$ と $\mathrm{SO}_{2}$ を吸収除去する方法である。さらに，全 乾式法は粉体噴射法, フィルタ法, 移動層法に, 半乾式 法はスラリ噴雺法, フィル夕法, 移動層法に分けられる。 粉体状またはスラリ状のアルカリ剤を吹込み，集じん装 置としてバグフィルタを採用している場合がフィル夕法 といわれている。全乾式法と半乾式法の中では, 粉体噴 射法またはスラリ噴霧法と集じん装置として電気集じん 装置（以下，EP と記す）を組み合わせた方法が最も多 く採用されている4,5)。ただし，1992 年にダイオキシン 類排出防止等ガイドラインが示され，バグフィルタの設 置が促進されるようになったことから，フィル夕法の採 用例が增加してきた。なお，この他に，2枚の隔離板間 に供給される酸化カルシゥム粒子の移動層に排ガスを通 過させて $\mathrm{HC} \ell$ と $\mathrm{SO}_{2}$ を除去する移動層法奋などが少数 採用されている。 
研究開発状況や運転状況等に関する報告はある ${ }^{6-21)}$ が, 各処理技術による $\mathrm{HC} \ell$ と $\mathrm{SO}_{2}$ の削娍量を詳細に検討し. た報告は見あたらない。

そこで本報告では，実際の都市ごみ焼却施設において 排ガス処理技術による $\mathrm{HC}$ とと $\mathrm{SO}_{2}$ の除去効果を調べる 実験を行うとともに, 排出濃度の実測值および文献值か ら処理技術の種類ごとに排出原単位を求め, 東京 23 区 と日本全国における都市ごみ焼却に伴う $\mathrm{HC} \ell$ と $\mathrm{SO}_{2}$ の 排出負荷量と排ガス処理技術による排出削減量を推算し た。

\section{2. 実験}

\section{1 䒾}

実験を行った都市ごみ焼却施設の仕様をTable 1 に 示す。Cの施設は流動床炬であり, その他の施設はス トーカ炉である。 A， B，Cの施設では炭酸カルシウムを 焼却炉内に吹き込む粉体噴射法と EP を組み合わせた方 法, D の施設では水酸化カルシゥムを煙道に吹き込む粉 体噴射法と EP を組み合わせた方法, E, F の施設では $\mathrm{EP}$ でダストを除去した排ガスを水酸化ナトリウム溶液 でほぼ中性に保った吸収液に吸収させる湿式法によって, 排ガス中の $\mathrm{HC} \boldsymbol{\ell}$ と $\mathrm{SO}_{2}$ を除去している。これらの施設 ではボイラ方式によって排ガスを冷却している。一方, 処理技術を採用していない $\mathrm{G}$ と $\mathrm{H}$ の施設では，焼却炉 出口の煙道に水を噴射する水噴射方式によって排ガスを 冷却している。

また,ごみ中のプラスチック類の乾ベースの重量構成 比は, C 以外の施設ではプラスチック類を分別収集して
いるので，約 $10 \%$ であったが，Cの施設ではプラス チック類を分けずに収集したごみを焼却しているため, 約 $16 \%$ であった。

\section{2 方 法}

処理技術を採用しない場合の排出濃度および粉体噴射 法と湿式法による除去効果を調べるために， A, B， C, $\mathrm{D}$ の施設ではアルカリ剂の吹込量をゼロから段階的に定 量に保ったときの $\mathrm{EP}$ 出口の排ガス中の $\mathrm{HC} \ell$ と $\mathrm{SO}_{2}$ の 濃度, $\mathrm{E}$ と $\mathrm{F}$ の施設では湿式法の排ガス処理装置の入 口と出口の排ガス中の $\mathrm{HC} \ell$ と $\mathrm{SO}_{2}$ の濃度, $\mathrm{G}$ と $\mathrm{H}$ の 施設では $\mathrm{EP}$ 出口の排ガス中の $\mathrm{HC} \ell$ と $\mathrm{SO}_{2}$ の濃度を测 定した。また， $\mathrm{A} の$ 施設ではアルカリ剤を吹き込まな いときの EP入口の濃度も测定し, EP のみによる除去 効果を調べた。HCl濃度はイオン電極方式の自動計測 器, $\mathrm{SO}_{2}$ 濃度は赤外線吸収方式または多成分演算型紫 外線吸収方式の自動計測器を使用して連続測定し，1時 間平均値を求めた。

さらに, $\mathrm{HC} \ell$ と $\mathrm{SO}_{2}$ の排出濃度の実測値と文献値と から求めた処理技術の種類ごとの平均排出濃度とごみ 1 $\mathrm{t}$ を焼却した場合の乾き排ガス量との積から，処理技術 の種類ごとに $\mathrm{HC} \ell$ と $\mathrm{SO}_{2}$ の排出原単位を算出した。そ して，これをもとに，排ガス処理技術の採用の経緯が明 確である東京 23 区の都市ごみ焼却施設を例にして，都 市ごみ焼却に伴う $\mathrm{HC} \ell$ と $\mathrm{SO}_{2}$ の大気環境への排出負荷 量と排ガス処理技術の採用による排出削減量の推移を詳 細に検討することによって排ガス処理技術の効果を明確 にするとともに，これまで明らかにされていなかった日 本全国における都市ごみ焼却に伴う $\mathrm{HC} \ell$ と $\mathrm{SO}_{2}$ の排出

Table 1 Specifications of municipal waste incinerators tested

\begin{tabular}{|c|c|c|c|}
\hline Incineration facility & A & B & $\mathrm{C}$ \\
\hline Type of incinerator & Stoker & Stoker & Fluidized-bed \\
\hline Capacity of incineration $(t / d)$ & 300 & 250 & 150 \\
\hline Volume of exhaust gas (wet) $\left(\mathrm{m}^{3} \mathrm{~N} / \mathrm{h}\right)$ & 75,000 & 64,000 & 42,000 \\
\hline Removal equipment of $\mathrm{HC} \ell$ and $\mathrm{SO}_{2}$ & $\begin{array}{l}\text { Injection of } \mathrm{CaCO}_{3} \\
\text { into furnace }\end{array}$ & $\begin{array}{l}\text { Injection of } \mathrm{CaCO}_{3} \\
\text { into furnace }\end{array}$ & $\begin{array}{l}\text { Injection of } \mathrm{CaCO}_{3} \\
\text { into furnace }\end{array}$ \\
\hline Removal equipment of dust & $\mathrm{EP}$ & $\mathrm{EP}$ & $\mathrm{EP}$ \\
\hline Incineration facility & $\mathrm{D}$ & $\mathrm{E}$ & $\mathbf{F}$ \\
\hline Type of incinerator & Stoker & Stoker & Stoker \\
\hline Capacity of incineration $(t / d)$ & 300 & 300 & 150 \\
\hline Volume of exhaust gas (wet) $\left(\mathrm{m}^{3} \mathrm{~N} / \mathrm{h}\right)$ & 70,000 & 75,000 & 43,000 \\
\hline Removal equipment of $\mathrm{HC} \ell$ and $\mathrm{SO}_{2}$ & $\begin{array}{l}\text { Injection of } \mathrm{Ca}(\mathrm{OH})_{2} \\
\text { into flue }\end{array}$ & Wet scrubber & Wet scrubber \\
\hline Removal equipment of dust & $\mathrm{EP}$ & EP & $\mathrm{EP}$ \\
\hline Incineration facility & G & $\mathrm{H}$ & \\
\hline Type of incinerator & Stoker & Stoker & \\
\hline Capacity of incineration $(t / d)$ & 250 & 150 & \\
\hline Volume of exhaust gas (wet) $\left(\mathrm{m}^{3} \mathrm{~N} / \mathrm{h}\right)$ & 66,000 & 45,000 & \\
\hline Removal equipment of $\mathrm{HC} \ell$ and $\mathrm{SO}_{2}$ & None & None & \\
\hline Removal equipment of dust & EP & EP & \\
\hline
\end{tabular}

EP: Electrostatic precipitator 
負荷量と排出削減量を 1992 年現在で推算した。

\section{3. 結果およひ考察}

\section{1 排出浱度}

3.1 .1 塩化水素・二酸化硫黄処理技術を採用しない場 合の排出濃度

$\mathrm{A} ， \mathrm{~B} ， \mathrm{C} ， \mathrm{D}$ の施設におけるアルカリ剤を吹き込まな い場合の EP 出口, E と F の施設における湿式法の排ガ ス処理装置入口, $\mathrm{G}$ と $\mathrm{H}$ の施設における $\mathrm{EP}$ 出口の $\mathrm{HC} \ell$ と $\mathrm{SO}_{2}$ の平均濃度の測定値（以下すべて $\mathrm{O}_{2} 12 \%$ 換算）と $\mathrm{EP}$ のみの施設における $\mathrm{HC} \ell$ 濃度と $\mathrm{SO}_{2}$ 濃度 の文献値 ${ }^{20-23)}$, またはいくつかの施設の自主測定値を, 焼却炉の焼却規模別に Fig. 1，2 に示す。

Fig. 1 より，処理技術を採用していない EP のみの施 設の $\mathrm{HC} \ell$ 濃度は，焼却規模によらないが, 多少のばら つきはあるものの, ごみ中のプラスチック類の分別方法 と排ガス冷却方法によって差がみられた ${ }^{1,9)}$ 。すなわち, プラスチック類を分別収集したごみを焼却している場合 の $\mathrm{HC} \ell$ 濃度は, 排ガス冷却方法が水噴射方式では平均 約 $300 \mathrm{ppm}$ ，ボイラ方式では平均約 $390 \mathrm{ppm}$ であるの に対して、プラスチック類を混合収集したごみを焼却し ている場合の $\mathrm{HC}$ 濃度は, 水噴射方式では平均約 580 $\mathrm{ppm}$, ボイラ方式では平均 $600 \mathrm{ppm}$ であった。一方,

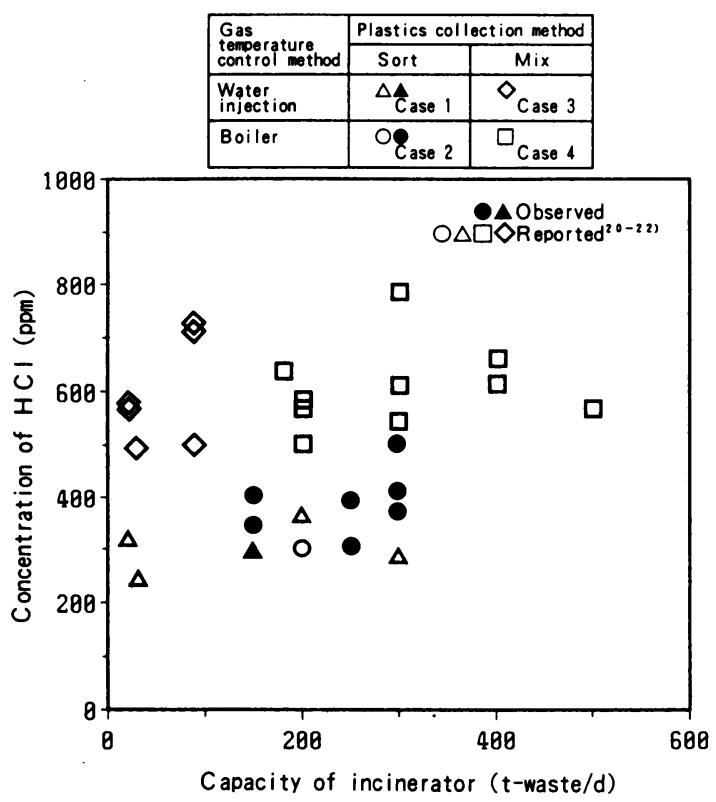

Fig. 1 Concentrations of $\mathrm{HC} \boldsymbol{\ell}$ from municipal waste incinerators (Electrostatic precipitator (EP) was adopted, but removal equipment of $\mathrm{HC} \boldsymbol{\ell}$ and $\mathrm{SO}_{2}$ was not adopted.)
Fig. 2 に示すように $\mathrm{SO}_{2}$ 濃度は焼却規模によらないが, 約 $20 \sim 65 \mathrm{ppm}$ の範囲でばらつくものの, プラスチッ ク類の分別方法や排ガス冷却方法の違いによる明確な差 はなく, 平均約 $44 \mathrm{ppm}$ であった。

また，Aの施設でアルカリ剤を吹き込まない場合で も, $\mathrm{EP}$ 入口ょり $\mathrm{EP}$ 出口で $\mathrm{HC} \ell$ と $\mathrm{SO}_{2}$ の濃度が低く, $\mathrm{EP}$ 内で $\mathrm{HC} \ell$ と $\mathrm{SO}_{2}$ が除去されていることがわかった。 そこで， $\mathrm{EP}$ 入口の $\mathrm{HC}$ 濃度または $\mathrm{SO}_{2}$ 濃度と (1) 式, （2）式によって算出した EP のみでの除去率との関係を Fig. 3 に示す。

ただし， $\eta_{\mathrm{H}}$ は $\mathrm{HC} \ell$ 除去率, $\mathrm{C}_{\mathrm{H}}$ と $\mathrm{C}_{\mathrm{H}}{ }^{\prime}$ はアルカリ剤 を吹き込まないときの $\mathrm{EP}$ 入口と出口の $\mathrm{HC} \ell$ 濃度, $\eta_{\mathrm{S}}$ は $\mathrm{SO}_{2}$ 除去率, $\mathrm{C}_{\mathrm{S} 0}$ と $\mathrm{C}_{\mathrm{s} 0}{ }^{\prime}$ はアルカリ剤を吹き込まな いときの $\mathrm{EP}$ 入口と出口の $\mathrm{SO}_{2}$ 濃度である。

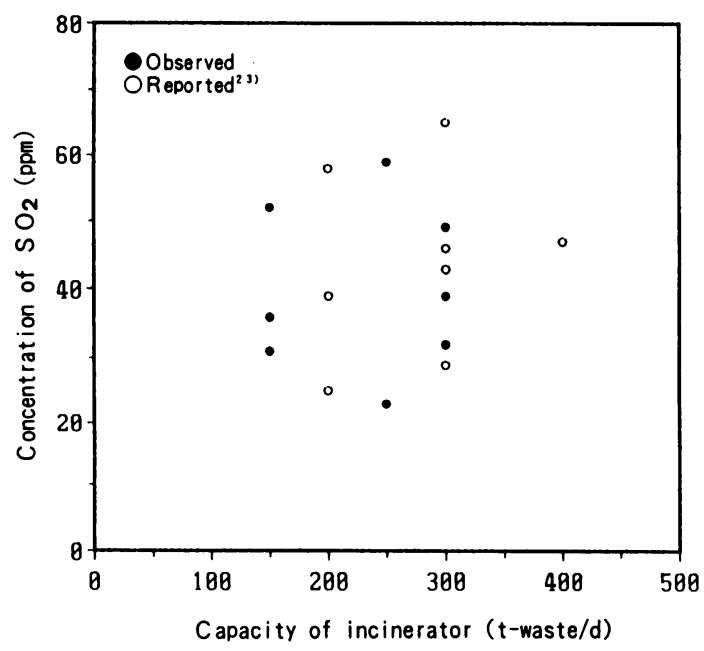

Fig. 2 Concentrations of $\mathrm{SO}_{2}$ from municipal waste incinerators (EP was adopted, but removal equipment of $\mathrm{HC} \boldsymbol{\ell}$ and $\mathrm{SO}_{2}$ was not adopted.)

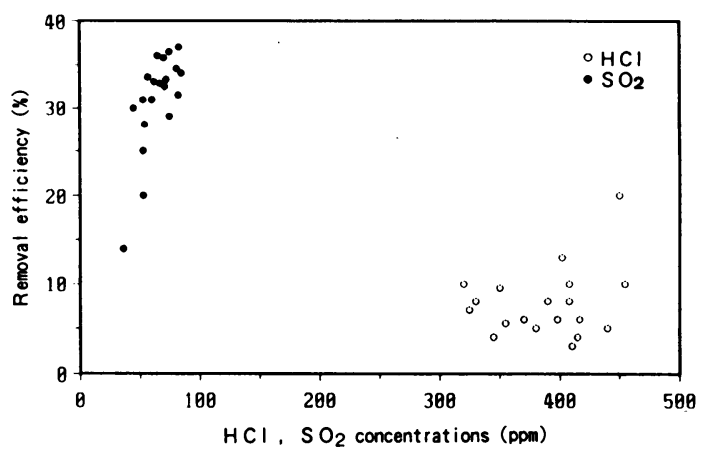

Fig. 3 Change of removal efficiency by EP with inlet $\mathrm{HC} \ell$ and $\mathrm{SO}_{2}$ concentrations 


$$
\begin{aligned}
& \eta_{\mathrm{H}}=100 \times\left(\mathrm{C}_{\mathrm{H} 0}-\mathrm{C}_{\mathrm{H} 0}{ }^{\prime}\right) / \mathrm{C}_{\mathrm{H} 0} \\
& \eta_{\mathrm{S}}=100 \times\left(\mathrm{C}_{\mathrm{S} 0}-\mathrm{C}_{\mathrm{S} 0}{ }^{\prime}\right) / \mathrm{C}_{\mathrm{S} 0}
\end{aligned}
$$

なお， $\mathrm{EP}$ 内で $\mathrm{HC} \ell$ と $\mathrm{SO}_{2}$ が除去される原因は，排ガ ス中のダストにカルシゥム等のアルカリ分が含まれてい ること, EP 内の排ガスの滞留時間が十数秒あることな どから, $\mathrm{HC} \ell$ と $\mathrm{SO}_{2}$ がダストと反応したためと考えら れる。

Fig. 3 より, $\mathrm{EP}$ での $\mathrm{HC} \ell$ と $\mathrm{SO}_{2}$ の平均除去率は, それぞれ約 $8 \%$ と約 $31 \%$ であった。そこで, $\mathrm{HC} \ell$ と $\mathrm{SO}_{2}$ の除去率は一定と仮定し, 前述の排出濃度加ら EP む $\mathrm{HC} \ell$ と $\mathrm{SO}_{2}$ の処理技術あ採用されていない施設にお ける $\mathrm{HC} \ell$ と $\mathrm{SO}_{2}$ の排出濃度を算出した。すなわち, こ れらの施設では排ガスは水噴射方式で冷却されているの で, $\mathrm{HC}$ 排出濃度は, プラスチック類を分別収集した ごみを焼却している場合には約 $330 \mathrm{ppm}$ ，プラスチッ ク類を混合収集したごみを焼却している場合には約 630 $\mathrm{ppm}$ と見積もった。また，同様の施設での $\mathrm{SO}_{2}$ 排出濃 度は約 $64 \mathrm{ppm}$ と見積もった。

\section{1 .2 全乾式法および半乾式法の除去率と排出濃度}

$\mathrm{A} ， \mathrm{~B} ， \mathrm{C} ， \mathrm{D}$ の施設における，アルカリ剂の $\mathrm{HC} \ell$ と $\mathrm{SO}_{2}$ の中和に必要な理論量に対する吹込当量比とアル カリ剤を吹き込まないときの EP 出口濃度を基準とした 除去率との関係を Fig. 4．５に示す。なお，各施設にお けるアルカリ斉を吹き込まないときの EP 出口濃度の変 動係数は, $\mathrm{HC} \ell$ で約 $10 \sim 13 \%, \mathrm{SO}_{2}$ で約 $10 \sim 20 \%$ と やや大きかったが, 高温の焼却炉内での濃度はアルカリ 剤を吹き込んであ変化しないとして，（3）式，（4）式に よって除去率を算出した。ただし， $\mathrm{C}_{\mathrm{Hp}}$ と $\mathrm{C}_{\mathrm{Sp}}$ はアルカ リ剂を吹き込んだ場合の $\mathrm{EP}$ 出口の $\mathrm{HC} \ell$ と $\mathrm{SO}_{2}$ の濃度

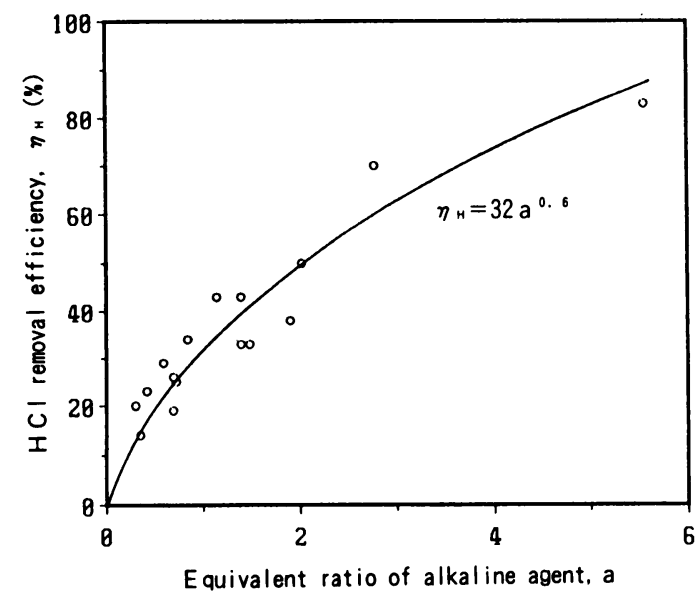

Fig. 4 Change of $\mathrm{HC} \boldsymbol{\ell}$ removal efficiency with equivalent ratio of alkaline agent in powder injection method
である。

$$
\begin{aligned}
& \eta_{\mathrm{H}}=100 \times\left(\mathrm{C}_{\mathrm{H} 0}^{\prime}-\mathrm{C}_{\mathrm{Hp}}\right) / \mathrm{C}_{\mathrm{H} 0}{ }^{\prime} \\
& \eta_{\mathrm{S}}=100 \times\left(\mathrm{C}_{\mathrm{S} 0^{\prime}}-\mathrm{C}_{\mathrm{Sp}}\right) / \mathrm{C}_{\mathrm{S} 0}{ }^{\prime}
\end{aligned}
$$

本実験の範囲内では，Fig. 4，5 の実線で示したように， $\mathrm{EP}$ と組み合わせた粉体噴射法の場合には, アルカリ剤 の吹込当量比 $\mathrm{a}$ と $\mathrm{HC}$ 除去率または $\mathrm{SO}_{2}$ 除去率との間 には（5）式,（6）式の関係が認められた。

$$
\begin{aligned}
& \eta_{\mathrm{H}}=32 \mathrm{a}^{0.6} \\
& \eta_{\mathrm{S}}=33 \mathrm{a}^{0.5}
\end{aligned}
$$

ただし，アルカリ剤を多く吹き込みすぎると，EPへの 負担が大きくなってばいじん排出濃度が高くなること， 焼却炉内にアルカリ剂を吹き込む方法では焼却炉内にお けるクリンカの生成が問題になること等から，東京 23 区の都市ごみ焼却施設では，通常のアルカリ斉の吹込当 量比は 1 程度に抑えられている。そこで各施設の運転条 件をこのように仮定すると，現実的な HCl除去率は $32 \%, \mathrm{SO}_{2}$ 除去率は $33 \%$ 程度となる。

したがって，EPを組み合わせた粉体噴射法が採用さ れ，プラスチック類を分別収集したごみを焼却している 場合の $\mathrm{HC}$ 排出濃度は, 排ガス冷却方法が水噴射方式 では約 $200 \mathrm{ppm}$ ，ボイラ方式では約 $270 \mathrm{ppm}$ と考えら れた。また，プラスチック類を混合収集したごみを焼却 している場合の $\mathrm{HC} \ell$ 排出濃度は, 水噴射方式では約 $390 \mathrm{ppm}$ ，ボイラ方式では約 $410 \mathrm{ppm}$ と考えられた。 さらに, EP を組み合わせた粉体噴射法が採用されてい る場合の $\mathrm{SO}_{2}$ 排出濃度は, 約 $30 \mathrm{ppm}$ と考えられた。

なお，原理が粉体噴射法と類似しているスラリ噴射法 は排ガスとの接触が良いので，その除去率は粉体噴射法

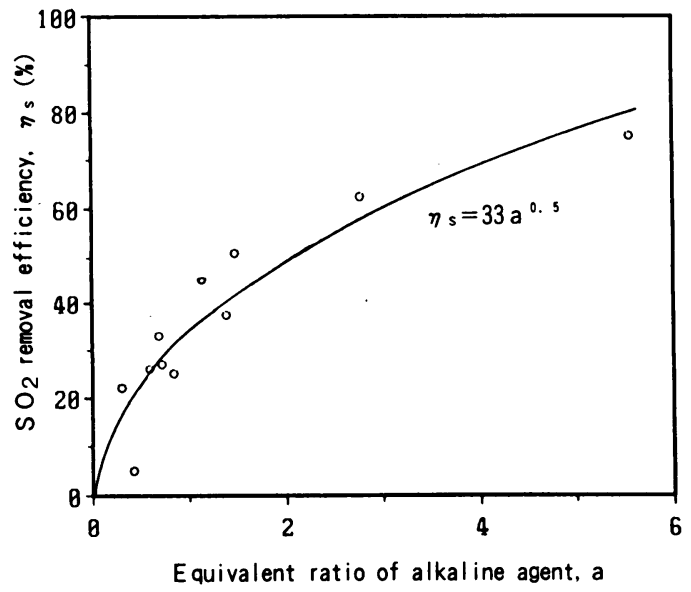

Fig. 5 Change of $\mathrm{SO}_{2}$ removal efficiency with equivalent ratio of alkaline agent in powder injection method 
の除去率より少し高くなることも考えられるがこここで は EP を組み合わせたスラリ噴霧法の場合の排出濃度も, $\mathrm{EP}$ を組み合わせた粉体噴射法の場合と同程度とみなし た。また，EPを組み合わせた移動層法の $\mathrm{HC} \ell$ と $\mathrm{SO}_{2}$ の排出濃度は, それぞれ約 $20 \sim 30 \mathrm{ppm}$, 約 $1 \sim 4$ ppm と報告されている6)ことから，それぞれ平均 25 $\mathrm{ppm}$ と平均 $3 \mathrm{ppm}$ と考えた。

一方, 乾式および半乾式のフィル夕法の $\mathrm{HC} \ell$ と $\mathrm{SO}_{2}$ の除去率は, バグフィルタでの排ガス温度とアルカリ剤 の吹込当量比に依存するが,一般に排ガス温度は約 180 $\sim 200^{\circ} \mathrm{C}$, 吹込当量比は約 $2 \sim 3$ の条件で運転管理され ている例が多く，このときの $\mathrm{HC} \ell$ と $\mathrm{SO}_{2}$ の排出濃度は, それぞれ約 $5 \sim 25 \mathrm{ppm}^{10-16)}$, 約 $2 \sim 10 \mathrm{ppm}$ 以下 ${ }^{13-19}$ と報告されている。したがって,フィル夕法の $\mathrm{HC} \ell$ と $\mathrm{SO}_{2}$ の排出濃度は, それぞれ平均約 $15 \mathrm{ppm}$ と平均約 $4 \mathrm{ppm}$ と考えた。

\section{1 .3 湿式法の除去率と排出濃度}

$\mathrm{E}$ と F の施設における湿式法の排ガス処理装置入口 の $\mathrm{HC} \ell お よ ひ ゙ \mathrm{SO}_{2}$ の濃度と除去率との関係を Fig. 6 に示す。 $\mathrm{HC} \ell$ 除去率と $\mathrm{SO}_{2}$ 除去率は（7）式または（8） 式により算出した。ただし， $\mathrm{C}_{\mathrm{HWi}}$ と $\mathrm{C}_{\mathrm{HW}}$ 。 は排ガス処理 装置入口と出口の $\mathrm{HC}$ l濃度, $\mathrm{C}_{\mathrm{swi}}$ と $\mathrm{C}_{\mathrm{sw}}$ は は排ガス処理 装置入口と出口の $\mathrm{SO}_{2}$ 濃度である。

$$
\begin{aligned}
& \eta_{\mathrm{H}}=100 \times\left(\mathrm{C}_{\mathrm{HWi}}-\mathrm{C}_{\mathrm{HWo}}\right) / \mathrm{C}_{\mathrm{HWi}} \\
& \eta_{\mathrm{s}}=100 \times\left(\mathrm{C}_{\mathrm{swi}_{\mathrm{i}}}-\mathrm{C}_{\mathrm{swo}_{\mathrm{o}}}\right) / \mathrm{C}_{\mathrm{swi}_{\mathrm{i}}}
\end{aligned}
$$

湿式法では, 約 $200 \sim 600 \mathrm{ppm}$ の幅広い $\mathrm{HC} \ell$ 濃度範囲 において, HCe除去率は平均約 98\% であった。一方, 約 $30 \sim 60 \mathrm{ppm}$ の $\mathrm{SO}_{2}$ 濃度範囲において, $\mathrm{SO}_{2}$ 除去 率は平均約 $96 \%$ であった。したがって, EP と湿式法

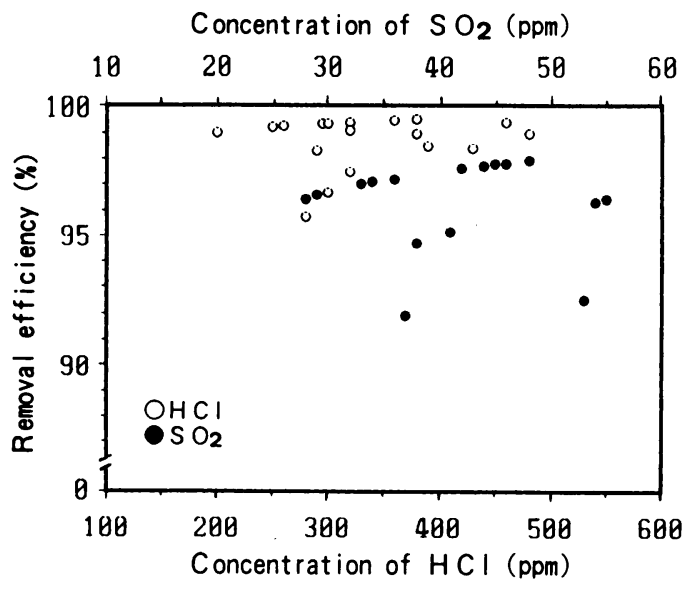

Fig. 6 Changes of $\mathrm{HC} \ell$ and $\mathrm{SO}_{2}$ removal efficiency with concentrations at inlet of wet scrubber
を組み合わせて採用し，プラスチック類を分別収集した ごみを焼却している場合の $\mathrm{HC}$ 排出濃度は, 排ガス冷 却方法が水噴射方式では約 $6 \mathrm{ppm}$, ボイラ方式では約 $8 \mathrm{ppm}$ と考えられ，また，プラスチック類を混合収集 したごみを焼却している場合の $\mathrm{HC} \ell$ 排出濃度は, 排ガ ス冷却方法にかかわらず約 $12 \mathrm{ppm}$ と考えた。さらに, $\mathrm{EP}$ と湿式法を組み合わせて採用している場合の $\mathrm{SO}_{2}$ 排出濃度は, プラスチック類の収集方法や排ガス冷却方 法によらず，約 $2 \mathrm{ppm}$ と考えた。

\section{2 排出原単位}

都市ごみ焼却に伴う $\mathrm{HC} \ell$ と $\mathrm{SO}_{2}$ の排出量の指標とし て, ごみ中の揮発性塩素含有量と㜣焼性硫黄含有量 ${ }^{24)}$ が 測定されており，それぞれ約 $0.3 \sim 0.5 \%$, 約 $0.02 \sim$ $0.03 \%$ であると報告されている ${ }^{25)}$ 。しかし, ごみ中の揮 発性塩素含有量と実際の焼却炉からの $\mathrm{HC} \ell$ の発生量と は必ずしも一致しない26)。また, 最終的な $\mathrm{HC} \ell$ と $\mathrm{SO}_{2}$ の排出濃度は処理技術によって異なる。そこで，3.1で 示した $\mathrm{HC \ell}$ と $\mathrm{SO}_{2}$ の排出濃度および都市ごみ $1 \mathrm{t}$ を焼 却したときの $\mathrm{O}_{2} 12 \%$ 換算の乾き排ガス量（以下，排ガ ス量原単位と記す）との積から，都市ごみ $1 \mathrm{t}$ の焼却に 伴う $\mathrm{HC} \ell$ と $\mathrm{SO}_{2}$ の排出原単位を算出した。その結果を Table 2，3に示す。

ごみの化学組成の測定結果 ${ }^{25)}$ から計算した排ガス量原 単位は, 約 $5,000 \sim 6,000 \mathrm{~m}^{3} \mathrm{~N} / \mathrm{t}$-waste となるが, 焼却 規模が $150 \sim 300$ t-waste/d のストーカ炉で実測した排 ガス量原単位は, 約 $5,400 \sim 6,500 \mathrm{~m}^{3} \mathrm{~N} / \mathrm{t}$-waste, 平均 約 $6,000 \mathrm{~m} \mathrm{~N} / \mathrm{t}$-waste であった。そこで，排出原単位の 算出にあたっては, 排ガス量原単位は実測の平均值であ る 6,000 $\mathrm{m}^{3} \mathrm{~N} / \mathrm{t}$-waste とした。

\begin{tabular}{|c|c|c|c|c|}
\hline \multirow{2}{*}{$\begin{array}{l}\text { Removal equipment of } \\
\mathrm{HC} \ell \text { and } \mathrm{SO}_{2}\end{array}$} & \multicolumn{4}{|c|}{ Emission unit (kg/t-waste) } \\
\hline & Case 1 & Case 2 & Case 3 & Case 4 \\
\hline None $1^{*}$ & 3.18 & - & 6.16 & - \\
\hline None $2 * *$ & 2.93 & - & 5.67 & - \\
\hline Powder injection and EP & 1.99 & 2.64 & 3.86 & 3.99 \\
\hline Slurry injection and EP & 1.99 & 2.64 & 3.86 & 3.99 \\
\hline Moving layer and EP & 0.24 & 0.24 & 0.24 & 0.24 \\
\hline Filter & 0.15 & 0.15 & 0.15 & 0.15 \\
\hline Wet scrubber and EP & 0.06 & 0.07 & 0.12 & 0.12 \\
\hline Wet scrubber and filter & 0.01 & 0.01 & 0.01 & 0.01 \\
\hline
\end{tabular}

Table 2 Emission units of $\mathrm{HC} \ell$

Case 1 : Plastics are sorted and gas temperature is controlled by water injection.

Case 2 : Plastics are sorted and gas temperature is controlled by boiler.

Case 3 : Plastics are not sorted and gas temperature is controlled by water injection.

Case 4 : Plastics are not sorted and gas temperature is controlled by boiler.

*: None or cyclone collector is adopted for dust removal.

** : EP is adopted for dust removal. 
Table 3 Emission units of $\mathrm{SO}_{2}$

\begin{tabular}{lc}
\hline $\begin{array}{l}\text { Removal equipment of } \mathrm{HC} \ell \\
\text { and } \mathrm{SO}_{2}\end{array}$ & $\begin{array}{l}\text { Emission unit } \\
(\mathrm{kg} / \mathrm{t} \text {-waste })\end{array}$ \\
\hline None $1^{*}$ & 1.09 \\
None $2^{* *}$ & 0.75 \\
Powder injection and EP & 0.51 \\
Slurry injection and EP & 0.51 \\
Moving layer and EP & 0.05 \\
Filter & 0.07 \\
Wet scrubber and EP & 0.03 \\
Filter and wet scrubber & 0.02 \\
\hline
\end{tabular}

$*$ : None or cyclone collector is adopted for dust removal.

**: EP is adopted for dust removal.

なお， $\mathrm{HC} \ell$ と $\mathrm{SO}_{2}$ の処理技術はダスト処理技術とし て EP またはバグフィルタが採用されているとした。ま た, フィル夕法怙よび移動層法での $\mathrm{HC} \ell$ 排出濃度の文 献值については, 焼却ごみ中のプラスチックの収集方法 と排ガス冷却方法が明らかにされていないので，これら の方法での $\mathrm{HC}$ l排出原単位は, プラスチックの収集方 法や排ガス冷却方法によらず同じ値とみなした。さらに, フィルタ法と湿式法を組み合わた方法での $\mathrm{HC} \ell$ と $\mathrm{SO}_{2}$ の排出濃度は, ともに $1 \mathrm{ppm}$ 未満と報告されている が, 排出原単位を求める際にはそれぞれ $1 \mathrm{ppm}$ とした。

\section{3 排出負荷量と排出削減量}

都市ごみ焼却に伴う $\mathrm{HC} \ell$ と $\mathrm{SO}_{2}$ の排出負荷量と排出 削減量を検討するには，排ガズ処理技術の導入状況を明 確にする必要がある。しかし，日本全国の都市ごみ焼却 施設における排ガス処理技術の採用状況の推移は明らか にされておらず，わずかに安藤ら ${ }^{5)}$ が 1992 年現在の有 害ガス除去設備と集じん装置の設置数を示しているだけ である。

そこで，まず，各処理技術の採用の経緯が明確である 東京 23 区の都市ごみ焼却施設を例にして, 都市ごみ焼 却に伴う $\mathrm{HC} \ell$ と $\mathrm{SO}_{2}$ の排出負荷量と排出削減量の推移 を詳細に検討した。次に, これをあとに 1992 年の日本 全国における排ガス処理技術の採用状況を推定し，都市 ごみ焼却に伴う $\mathrm{HCl} \ell$ と $\mathrm{SO}_{2}$ の排出負荷量と排出削減量 を推算することとした。

\section{3.1 東京 23 区における排出負荷量と排出削減量}

東京 23 区の都市ごみ焼却施設では, プラスチック類 を分別収集して焼却ごみ中への塩素系プラスチックの混 入をできるだけ抑えながら， $\mathrm{HC} \ell$ と $\mathrm{SO}_{2}$ の処理技術と して, 1979 年から一部の建替え予定施設を除いた既設 の施設には EP を組み合わせた粉体噴射法を, 新設の施 設には EP と組み合わせた湿式法またはフィル夕法と湿 式法を組み合わせた方法等を採用している。なお, 建替 え予定施設では水噴射方式, その他の施設ではボイラ方

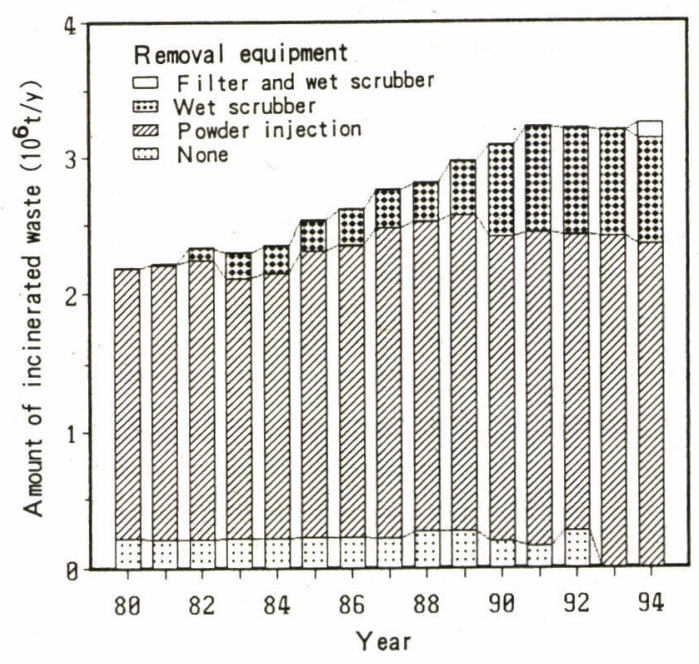

Fig. 7 Amounts of incinerated waste in facilities equipped each removal method of $\mathrm{HC} \ell$ and $\mathrm{SO}_{2}$ in the ward areas of Tokyo

式によって排ガスを冷却していた。

1980 年から 15 年間の各処理技術を採用した施設の焼 却ごみ量 ${ }^{28)}$ の推移を Fig. 7 に示す。この焼却ごみ量の 推移と Table 2,3 に示した $\mathrm{HC} \ell$ と $\mathrm{SO}_{2}$ の排出原単位 とから計算した $\mathrm{HC} \ell$ と $\mathrm{SO}_{2}$ の排出負荷量と排出削減量 の経年変化を Fig. 8，9 に示す。焼却ごみ量は 1980 年 から 1991 年までに約 1.4 倍に増加してその後はほぼ一 定となっているが, 1994 年の $\mathrm{HC} \ell$ と $\mathrm{SO}_{2}$ の排出負荷量 は，処理技術，特に湿式法の採用によって 1980 年と比 べて微増傾向に抑えることができ，それぞれ約 $6.2 \times$ $10^{3} \mathrm{t} / \mathrm{y}$ と約 $1.3 \times 10^{3} \mathrm{t} / \mathrm{y}$ となっている。また, 処理技 術による $\mathrm{HC} \ell と \mathrm{SO}_{2}$ の排出負荷削減量は，それぞれ約 $6.1 \times 10^{3} \mathrm{t} / \mathrm{y}$ と約 $1.1 \times 10^{3} \mathrm{t} / \mathrm{y}$ であり, 排出負荷量と 同程度となっていた。

\subsection{2 日本における排出負荷量と排出削隇量}

有害ガス除去設備および集じん装置の設置数 ${ }^{5}$ から, 各処理技術とダスト処理技術の焼却ごみ量換算の採用率 を推算してみたところ, Table 4 に示すような結果が得 られた。これらの数値と 1992 年の焼却ごみ量の約 3.65 $\times 10^{7} \mathrm{t} / \mathrm{y}^{29)}$ および排出原単位とから 1992 年の日本全 国における都市ごみ焼却に伴う $\mathrm{HC} \ell$ と $\mathrm{SO}_{2}$ の排出負荷 量と排出削減量を推算してみた。

推算にあたっては, 移動層法の採用例は極めて少ない ので，粉体噴射法またはスラリ噴霧法（以下噴射法と記 す), フィル夕法, 湿式法について計算した。また, $\mathrm{HC} \ell$ と $\mathrm{SO}_{2}$ の処理技術を採用していない場合の推算で は，プラスチック類は分別されて排ガス温度の低減方法 は水噴射方式とした。さらに，噴射法または湿式法を採 


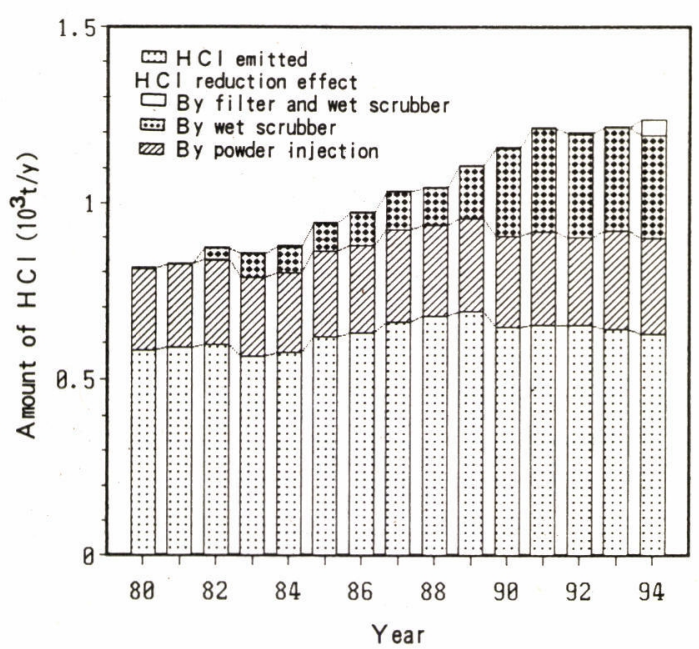

Fig. $8 \mathrm{HC} \ell$ reduction effect by removal equipment of $\mathrm{HC} \ell$ and $\mathrm{SO}_{2}$ in the ward areas of Tokyo

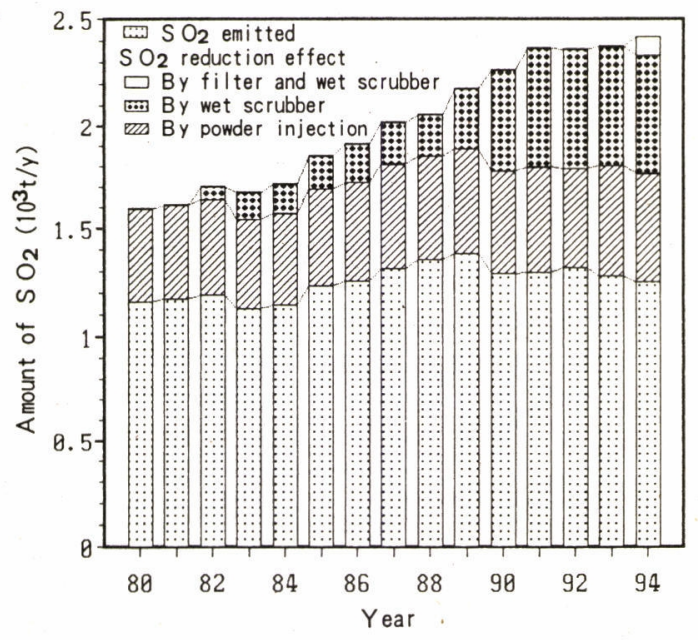

Fig. $9 \mathrm{SO}_{2}$ reduction effect by removal equipment of $\mathrm{HC} \ell$ and $\mathrm{SO}_{2}$ in the ward areas of Tokyo

用している場合の推算では, 自治体の約 5 割がプラス チック類を分別し，約 8 割が排ガス温度をボイラ方式で 低減していること呮を考慮した。

この結果, 1992 年の日本全国における都市ごみ焼却 に伴う $\mathrm{HC} \ell$ と $\mathrm{SO}_{2}$ の排出負荷量は, それぞれ約 $9.1 \times$ $10^{4} \mathrm{t} / \mathrm{y}$ と約 $1.8 \times 10^{4} \mathrm{t} / \mathrm{y}$ と推算された。さらに，排ガ ス処理技術による $\mathrm{HC} \ell$ と $\mathrm{SO}_{2}$ の排出削減量は, Table 5 のように推算され, それぞれ合計約 $7.6 \times 10^{4} \mathrm{t} / \mathrm{y}$ と 約 $2.0 \times 10^{4} \mathrm{t} / \mathrm{y}$ と推算された。

日本全国の都市ごみ焼却施設以外の排出源からの HC 総排出量は報告されていないので, 都市ごみ焼却施設
Table 4 Adopted ratios of removal equipment of $\mathrm{HC} \ell$ and $\mathrm{SO}_{2}$ in municipal waste incinerators in Japan (1992)

\begin{tabular}{ccccc}
\hline \multicolumn{5}{c}{ Removal equipment of $\mathrm{HC} \ell$ and $\mathrm{SO}_{2}$} \\
\hline None $1^{*}$ & None $2{ }^{* *}$ & Injection & Filter & Wet scrubber \\
\hline $9.1 \%$ & $19.1 \%$ & $50.7 \%$ & $2.9 \%$ & $18.2 \%$ \\
\hline
\end{tabular}

*: None or cyclone collector is adopted for dust removal. ** : EP is adopted for dust removal.

Table 5 Removed amounts of $\mathrm{HC} \ell$ and $\mathrm{SO}_{2}$ by $\mathrm{EP}$ and removal equipment in municipal waste incinerators in Japan (1992)

\begin{tabular}{ccccccc}
\hline & & \multicolumn{4}{c}{ Removal equipment of $\mathrm{HC} \ell$ and $\mathrm{SO}_{2}$} \\
\cline { 3 - 6 } Gas & EP & Injection & Filter & Wet scrubber & Total \\
\hline $\mathrm{HC} \ell$ & $\left(10^{3} \mathrm{t} / \mathrm{y}\right)$ & 2 & 35 & 5 & 34 & 76 \\
$\mathrm{SO}_{2}\left(10^{3} \mathrm{t} / \mathrm{y}\right)$ & 2 & 10 & 1 & 7 & 20 \\
\hline
\end{tabular}

の寄与率は不明である。一方, 1970, 1980, 1983 年の $\mathrm{SO}_{2}$ 総排出量は, それぞれ約 $5.30 \times 10^{6} \mathrm{t} / \mathrm{y}$, 約 1.26 $\times 10^{6} \mathrm{t} / \mathrm{y}$, 約 $1.08 \times 10^{6} \mathrm{t} / \mathrm{y}^{31)}$ と報告されている。し たがって, $\mathrm{SO}_{2}$ 総排出量が 1983 年からほとんど変化が ないとすると, 1992 年における都市ごみ焼却施設の $\mathrm{SO}_{2}$ 排出の総排出量に対する寄与率は約 $1.7 \%$ となる。

\section{4. 結一論}

都市ごみ焼却施設において, $\mathrm{HC} \ell$ と $\mathrm{SO}_{2}$ の処理技術 等の適用が $\mathrm{HCl}$ と $\mathrm{SO}_{2}$ の排出濃度におよぼす影響を明 らかにし，これらと排ガス量とから処理技術の種類ごと に $\mathrm{HC} \ell$ と $\mathrm{SO}_{2}$ の排出原単位を求め, 東京 23 区と日本 全国における都市ごみ焼却に伴う $\mathrm{HC} \ell$ と $\mathrm{SO}_{2}$ の排出負 荷量と排ガス処理技術による排出削減量を検討したとこ ろ, 次の結果が得られた。

(1) $\mathrm{HC} \ell$ と $\mathrm{SO}_{2}$ の処理技術を採用していない場合の $\mathrm{HC} \ell$ 排出濃度は, ごみ中のプラスチック類の分別方 法, 排ガス冷却方法, 集じん装置の種類によって異な るが, 約 $300 〜 650 \mathrm{ppm}$ であった。また, $\mathrm{SO}_{2}$ 排出 濃度は，集じん装置の種類によって異るが，約 44 $64 \mathrm{ppm}$ であった。

(2) 電気集じん装置（EP）を組み合わせた粉体噴射法 を採用している場合の $\mathrm{HC} \ell$ 排出濃度は, 約 200 $410 \mathrm{ppm}, \mathrm{SO}_{2}$ 排出濃度は約 $30 \mathrm{ppm}$ であった。また, $\mathrm{EP}$ を組み合わせたスラリ噴射法を採用している場合 あ同程度とみなした。

（3） EP を組み合わせた湿式法を採用している場合の $\mathrm{HC} \ell$ 排出濃度は約 $6 \sim 12 \mathrm{ppm}, \mathrm{SO}_{2}$ 排出濃度は約 2 ppmであった。

(4) 東京 23 区では, 1980 年からの 15 年間に焼却ごみ 量は約 1.4 倍に増加したが, 排ガス処理技術の採用に 
よって $\mathrm{HC} \ell と \mathrm{SO}_{2}$ の排出負荷量は微增に抑えられて いることがわかった。

（5） 1992 年の日本全国における都市ごみ焼却に伴う $\mathrm{HC} \ell と \mathrm{SO}_{2}$ の排出負荷量は, それぞれ約 $9.1 \times 10^{4} \mathrm{t} /$ $\mathrm{y}$ と約 $1.8 \times 10^{4} \mathrm{t} / \mathrm{y}$ であると推算された。また, 排 ガス処理技術による $\mathrm{HCl}$ と $\mathrm{SO}_{2}$ の排出削減量は， そ れぞれ約 $7.6 \times 10^{4} \mathrm{t} / \mathrm{y}$ と約 $2.0 \times 10^{4} \mathrm{t} / \mathrm{y}$ であると推 算された。

\section{考文献}

1）平山直道：都市ご烧却炬における塩化水素ガス対策， 公害と対策, 第 15 巻, 第 8 号, pp. 1110-1114 (1979)

2）武田信生：廃裹物の赎却による有害物質の発生と対策, 安全工学, 第 29 巻, 第 6 号, pp. 407-414（1990)

3）松浦重治, 稲田武彦：規制対象排カスに対する処理技 術, 廃裹物学会誌, 第 2 巻, 第 4 号, pp. 318-330 (1991)

4）小川忠彦：ごみ焼却工場における排ガス処理施設の実 態と問題点，廃衰物学会誌，第 2 巻，第 4 号，pp. 298 -305 (1991)

5）安藤 茂，小林陽一：特別管理一般廃衰物であるばいじ んの適正处理について，廃桻物学会誌，第 5 巻，第 1 号, pp. 18-31 (1994)

6）井手義弘，守岡修一：生石灰移動層式塩化水素除去装 置，環境技術，第 14 巻，第 10 号，pp. 817-825 (1985)

7）花谷友二, 守岡修一, 原田和敏：簡易吹込法による塩 化水素除去装置の性能について，第 10 回全国都市清掃 研究発表会講演論文集, pp. 135-137（1989）

8）酒井 泰：塩化水素除去施設稳㗢状況報告, 都市之廃衰 物，第 13 巻，第 9 号，pp. $19-28$ (1983)

9）四阿秀雄，田原祐介，近藤高一：こみ焼却炬における 塩化水素対策の実際，公害と対策，第 14 巻，第 10 号， pp. 1059 - 1114 (1979)

10）藤原直機，伊東明治，佐藤政樹，大村栄治：ごみ焼却 炉の有害ガス除去, 第 3 回廃衰物学会研究発表会講演 論文集, pp. 315-318 (1992)

11）木村哲男, 川本克也, 佐藤 犜: ごみ烧却排ガスの乾式 処理, 第 12 回全国都市清掃研究発表会講演論文集, pp. 156 - 158 (1991)

12）福岡大作, 二村 修, 宮村 彰, 小澤さや加, 竹中伸也, 浦上嘉信：都市ごる焼却炉におけるバグフィルタを使 用した排ガス処理技術の開発，萑原インフィルコ時報， 第 108 号, pp. 32-38 (1993)

13） 小林忠夫, 富澤成元：高効率総合排ガス処理装置の運 転, 第 9 回全国都市清掃研究発表会講演論文集, pp. $157-159$ (1988)
14）平岡正勝, 藤井達宏, 柏原憲治, 家山一夫, 斉藤正 治：万過式集じん装置の有害ガス除去性能，第11 回全 国都市清掃研究発表会講演論文集, pp. 134-136 (1990)

15）剛田光吉：バグフィル夕採用の総合排ガス処理技術と 運転, 都市之廃重物, 第 21 巻, 第 10 号, pp. $41-53$ (1991)

16）秋山 肇，平井晴人，能登 隆：都市ご流動床炉の夕 イオキシン類排出特性，第 14 回全国都市清掃研究発表 会講演論文集, pp. $178-180$ (1993)

17）溸地 實，福永 勲，中川伊造：万過式集じん装置によ 了 $\mathrm{HC} \ell, \mathrm{SO}_{2}$ の除去特性, 第 10 回全国都市清掃研究 発表会講演論文集, pp. 138 - 140 (1989)

18）村井正和，中川伊造，田中信行，角田芳忠：バグフィ ル夕を設置したバッチ運転炉の起動・停止における運 転特性, 第 11 回全国都市清掃研究発表会講演論文集, pp. $131-133$ (1990)

19）魚屋和夫，武井 彰，貝原裕二，小瀬公利, 小林勝彦： 脱硝バグフィルタによる有害ガス処理，第 14 回全国都 市清掃研究発表会講演論文集, pp. 160 - 162 (1993)

20）村松富美雄，三村春雄，相原敬次，箖㥓光夫：都市こ 子焼却炬における塩化水素排出量原単位, 神奈川県公 害センター年報, 第 12 号, p. 39 (1981)

21）石黒辰吉, 岩崎好陽, 福島 悠, 小野塚春吉：連続機械 式都市コミ焼却炝からの排ガスの湘定とその問题点, 公害と対策，第 10 巻，第 5 号，pp. 421-433（1974）

22）鹿田幸雄, 船造俊一, 立溒邦人：清掃工場における塩 化水素の連続椡定について, 都市と廃裹物, 第 5 巻, 第 10 号, pp. 24-32 (1978)

23）東京都清掃局：事業概要, 昭和 54 年版 (1979)

24）厚生省環境衛生局水道環境部環境整钽課編集：こみ焼 却施設各種試験マニュアル, 全国都市清掃会議, pp. $10-11(1983)$

25）武本敏男，今井俊多，大木秀男，大山征三郎，恩田敏 雄, 谷川 昇, 立菌邦人: 平成 6 年度こみ質調查, 平成 6 年度東京都清掃研究所研究報告, pp. 9-35 (1996)

26）平岡正勝, 武田信生, 藤田勝康：都市ご燒却炬にお ける塩化水素の発生と挙動, 公害と対策, 第 15 巻, 第 8 号, pp. 1102-1109 (1979)

27） 東京都清掃局: 事業概要, 平成 7 年版（1995）

28）東京都清掃局：清掃局年報，昭和 55 年版 平成 6 年版 (1981 1995)

29）厚生省生活衛生局水道㻴境部環境整備課：日本の廃衰 物処理平成 4 年度版 (1995)

30）プラスチック処理促進協会：平成 5 年度都市こみ中の プラスチック収集方法の実態及びトレンド調査報告書, pp. $9-10$ (1994)

31）環境庁長官官房総務課編集：地球環境キーワード事典, 中央法規出版，p. 49 (1990) 


\title{
Emitted and Removed Levels of $\mathrm{HC} \ell$ and $\mathrm{SO}_{2}$ from Municipal Waste Incinerators
}

\author{
Noboru Tanikawa* and Kohei Urano** \\ * Tokyo Metropolitan Research Institute for Waste Management \\ ** Laboratory of Safety and Environmental Engineering, Faculty \\ of Engineering, Yokohama National University \\ 'Correspondence should be addressed to Noboru Tanikawa : \\ ( 2 Aomi, Koto-ku, Tokyo, 135 Japan)
}

\begin{abstract}
$\mathrm{HC} \ell$ and $\mathrm{SO}_{2}$ concentrations in flue gas from municipal waste incinerators were investigated for different removal equipment for $\mathrm{HC} \ell$ and $\mathrm{SO}_{2}$. The emitted and removed levels of $\mathrm{HC} \ell$ and $\mathrm{SO}_{2}$ from the municipal waste incinerators in the ward areas of Tokyo and throughout Japan were estimated.

When the removal equipment was not used, the mean concentration of $\mathrm{HC} \ell$ ranged from 300 to $650 \mathrm{ppm}$. This range was dependent on the sorting and collection method of plastics in the waste, gas temperature control methods, and dust removal methods. The mean concentration of $\mathrm{SO}_{2}$ ranged from 44 to $63 \mathrm{ppm}$, and was dependent on dust removal methods.

In the case where the calcium powder injection method and the electrostatic precipitator (EP) were adopted, the mean concentrations of $\mathrm{HC} \ell$ and $\mathrm{SO}_{2}$ ranged from 200 to $410 \mathrm{ppm}$, and $30 \mathrm{ppm}$, respectively. In the case where $\mathrm{EP}$ and a wet scrubber were adopted, the mean concentration of $\mathrm{HC}$ $\ell$ ranged from 6 to $12 \mathrm{ppm}$, and the mean concentration of $\mathrm{SO}_{2}$ was about $2 \mathrm{ppm}$.

In the ward areas of Tokyo, the amount of incinerated waste in 1994 increased by 1.4 times over that for 1980. However, the amount of $\mathrm{HC} \ell$ and $\mathrm{SO}_{2}$ that was emitted from municipal waste incinerators in 1994 was slightly higher than those in 1980 because of the adoption of removal equipments.

In Japan overall, the emitted amount of $\mathrm{HC} \ell$ and $\mathrm{SO}_{2}$ from municipal waste incinerators in 1992 was estimated to be $9.1 \times 10^{4} \mathrm{t} / \mathrm{y}$ and $1.8 \times 10^{4} \mathrm{t} / \mathrm{y}$, respectively. And the removed amount was estimated to be $7.6 \times 10^{4} \mathrm{t} / \mathrm{y}$ and $2.0 \times 10^{4} \mathrm{t} / \mathrm{y}$, respectively.
\end{abstract}

Key words : municipal waste incineration, $\mathrm{HC} \ell, \mathrm{SO}_{2}$, emission, flue gas treatment 